[11] Baerveldt, A. J., Klang, R., "A low-cost and low-weight attitude estimation system for an autonomous helicopter", In Proceedings of IEEE International Conference on Intelligent Engineering Systems, IEEE, pp. 391-395, 1997.

[12] Min, H. G., Jeung, E. T., "Complementary filter design for angle estimation using mems accelerometer and gyroscope", Department of Control and Instrumentation, Changwon National University, Changwon, Korea, 641$773,2015$.

[13] Gordeev V.N., (2016). "Kvaternionyi i bikvaternionyi s prilozheniyami v geometrii i mehanike", Izdatelstvo "Stal", Kiev, 316 p., 2016. ISBN 978-617-676-099-3.

[14] Perumal, L., "Quaternion and its application in rotation using sets of regions", International Journal of Engineering and Technology Innovation, 1(1), 35, 2011.

[15] Madgwick, S., "An efficient orientation filter for inertial and inertial/magnetic sensor arrays", Report x-io and University of Bristol (UK), 25, 113-118, 2010.

[16] Inertial labs. (2020). Attitude and Heading Reference System AHRS-10 Datasheet. Retrieved from: https://inertiallabs.com/products/ahrs/.

УДК 664.1: 65.011.56

\title{
АВТОМАТИЗАЦІЯ ОПЕРАТИВНОГО ОБЛІКУ ЦУКРОВОГО УТФЕЛЮ В МОДЕРНІЗОВАНІЙ СИСТЕМІ КЕРУВАННЯ ДЛЯ ПРОДУКТОВОГО ВІДДІЛЕННЯ ЦУКРОВОГО ЗАВОДУ
}

\section{Скаковський Ю. М.}

Одеська національна академія харчових технологій, Одеса, Україна

ORCID: http://orcid.org/0000-0003-4888-4469

yurysk@ukr.net

Copyright (C) 2020 by author and the journal "Automation of technological and business - processes. This work is licensed under the Creative Commons Attribution International License (CC BY). http://creativecommons.org/licanses/by/4.0

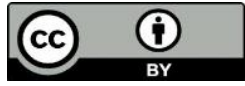

ONAFT

Open Access

DOI: https://doi.org/10.15673/atbp.v12i3.1922

\begin{abstract}
Анотація. Розглядаються технічні рішення з розробки підсистеми автоматичного оперативного обліку иукрового утфелю в модернізованій системі керування для продуктового відділення иукрового виробництва. Наведений аналіз відомих рімень із розробки аналогічних систем. Проведені лабораторні дослідження програми оперативного обліку иукрового утфелю, щчо був зварений у вакуум-апараті періодичної дї (ВА) протягом зміни. Програма була складена FBD подібною мовою програмування контролера МІК52 українського виробництва. Імітаційне моделювання підсистеми проводилось на спеціалізованому стенді із застосуванням промислових контролерів та програмних засобів украӥнського виробництва, в тому числі SCADA-системи «IНДЕЛ». Для зв'язку програмованого контролера та комп'ютера використаний перетворювач інтерфейсів MODBUS RTU - USB типу БПI-52. Наведені результати моделювання підсистеми оперативного обліку утфелю, аналіз котрих дозволяє зробити висновки про працездатність розроблених алгоритмів та програм. Інтегрування розробленої підсистеми обліку утфелю до системи автоматизованого керування (САК) прочесами у ВА дозволило розширити перелік функиій, шео виконуються у САК, та підвищити інтелектуальні можливості системи. Отримані позитивні результати проведеного дослідження дозволили сформувати рекомендації та пропозииії до модернізації АСКТП продуктового відділення, на основі методики автоматизованих розрахунків традиційних показників обліку виробництва иукрового заводу. Розроблена промислова версія АРМ оператора-варщика, котра запропонована до впровадження. Крім того, за отриманими результатами були визначені напрямки подальших досліджень САК технологічними процесами иукрового заводу.
\end{abstract}

Abstract. Technical solutions to develop the subsystem of automatic operational accounting for sugar massecuite in modernized control system for food department of sugar production are considered. The analysis of known solutions to develop similar systems was done. Laboratory studies of the program for operational accounting of sugar massecuite that was brewed in batch pan (VA) during the shift were conducted. The program was compiled in FBD-like programming language for 
http://www.atbp.onaft.edu.ua/

Ukrainian-made MIK52 controller. The simulation of subsystem was carried out at specialized bench using industrial controllers and software of Ukrainian production including SCADA system INDEL. To ensure communication between programmable controller and computer, MODBUS RTU converter - USB interface type BPI-52 was used. Simulation results of the massecuite operational accounting subsystem are presented, its analysis allows to draw conclusions about working capacity of developed algorithms and programs. Integration of developed massecuite accounting subsystem into the automated control system (ACS) of processes in VA allowed to expand the list of functions performed in ACS and increase the intellectual capabilities of the system. The obtained positive results of the study enabled to formulate recommendations and proposals for ACS of technological processes in food department modernization based on the methodology of traditional indicators' automated calculations for sugar plants production. The industrial version of operator-cooker's automated workplace has been developed and is proposed for implementation. In addition, according to obtained results, the directions for further research of ACS for technological processes of sugar factory were determined.

Ключові слова: Система автоматизованого керування (САК), автоматизоване робоче місце (АРМ) оператора, мікропроцесорний контролер, оперативний облік утфелю, програма керування, вакуум-апарат періодичної дії (ВА), продуктове відділення, цукровий завод.

Keywords: Automated control system (ACS), automated workplace (AWP), microprocessor-based controller, operative accounting of massecuite, control program, batch pan, grocery department, sugar plant.

\section{Вступ}

В Одеській національній академії харчових технологій в межах госпдоговірної тематики виконуються роботи із надання науково-технічної допомоги при модернізації систем автоматизації для підвищення ефективності їх функціонування на Красилівському бурякоцукровому заводі (Хмельницької області). Розроблена та впроваджена система автоматизованого керування (САК) процесом уварювання цукрового утфеля у вакуум-апараті (ВА) періодичної дії у вигляді АРМ оператора-варщика, що базується на використанні технічних і програмних засобів українського виробництва [1]. На теперішній час, в зв'язку із реконструкцією технологічної схеми продуктового відділення, котра супроводжується модернізацією системи автоматизованого керування (АСКТП) на основі отриманих позитивних результатів промислових випробувань АРМ оператора-варщика, доцільно окрім задач керування розглянути задачі автоматичного оперативного обліку напівпродукту у продуктовому відділенні, що дозволить суттєво підвищити якість сервісу для служби головного технолога заводу, точність розрахунків, котрі традиційно виконуються робітниками цієї служби.

\section{Аналіз літературних джерел і постановка проблеми}

Більшість цукрових заводів оснащені системами комерційного обліку, які забезпечують: автоматизований облік сировини, що надходить на підприємство, облік готової продукції, що надходить на склад та відпускається споживачам. Однак, функції обліку внутрішніх запасів напівпродуктів, що знаходиться в проміжних ємностях і апаратах, i їхнє переміщення по технологічному тракту залишалися неавтоматизованими і реалізовувалися персоналом служби головного технолога вручну, відповідно до традиційної методики [2].

Операції по зняттю вихідних даних для подібних розрахунків $є$ досить трудомістким, дуже висока їхня погрішність. Використання даних журналів операторів, наприклад, журнал звареного цукрового утфелю на ділянці кристалізації також приводить до істотної погрішності обумовленої людським фактором.

Найбільш успішні спроби рішення подібних задач у складі АСКТП цукрового заводу наведені у [2]. Але реалізація цих задач була виконана вже застарілими на теперішній час технічними та програмними засобами, що потребує додаткових досліджень, розробки та випробувань з використанням актуальних програмованих контролерів та комп’ютерів.

Реалізація задачі автоматичного оперативного обліку сировини (бурякової стружки) на базі сучасних технічних і програмних засобів була вирішена у складі модернізованої АСКТП дифузійного відділення [3].

Таким чином, для реалізації задачі автоматичного оперативного обліку утфелю у складі модернізованої АСКТП продуктового відділення необхідно, використовуючи досвід відомих розробок та враховуючи досвід робітників служб головного технолога та КВП і А даного заводу з роботи і обслуговування мікропроцесорних контролерів та регуляторів фірми «МІКРОЛ» (м. Івано-Франківськ), а також SCADA-системи «ІНДЕЛ», котра також являє собою сучасний програмний засіб вітчизняного виробництва, створений на підприємстві «Інфотехпром» (м. Полтава), який використано в більшості АРМ операторів на інших ділянках заводу, розробити підсистему оперативного обліку утфелю та інтегрувати іiі до складу АРМ оператора-варщика.

\section{Мета і завдання дослідження}

Мета й завдання передпроєктних досліджень для створення АРМ оператора-варщика з інтегрованої до його складу підсистемою оперативного обліку утфелю полягала в зборі вихідних даних про необхідну для подання інформацію, бажану форму подання цієї інформації, визначення необхідної періодичності опитування даних, котра виключала би втрату інформації, а також в проведенні аналізу можливих варіантів структури системи, алгоритмічних рішень, вибору технічних та програмних засобів для їхньої реалізації з остаточним узгодженням пропонованої концепції із технічним керівництвом заводу. За узгодженням зі спеціалістами ЗАМОВНИКА обраний перелік вихідних даних, що 
контролюються автоматично, та варіант програмної реалізації алгоритму обліку, котрий базується на використанні сигналу відключення ВА від вакуумної магістралі, що здійснюється після відключення апарату від пари, що гріє (закриття ВП2), та передує підключенню внутрішнього середовища ВА до атмосфери та випуску готового утфелю до утфелемішалки. На рис. 1 наведено апаратурно-технологічну схему ВА, де зображені виконавчі пристрої (ВП1, ВП2, ВП3 та ВП5), з використанням котрих реалізуються означені допоміжні операції оператором 3 дистанційного пульта відповідними тумблерами [1].

Важливою обставиною $є$ те, що рішення задачі оперативного обліку утфелю здійснюється на базі тих же технічних засобів, що використані за створенням АРМ оператора-варщика, за рахунок резервів їхніх інформаційно-обчислювальних можливостей, і не вимагає залучення додаткових обчислювальних ресурсів.

Наведені обставини визначають актуальність розглянутої задачі.

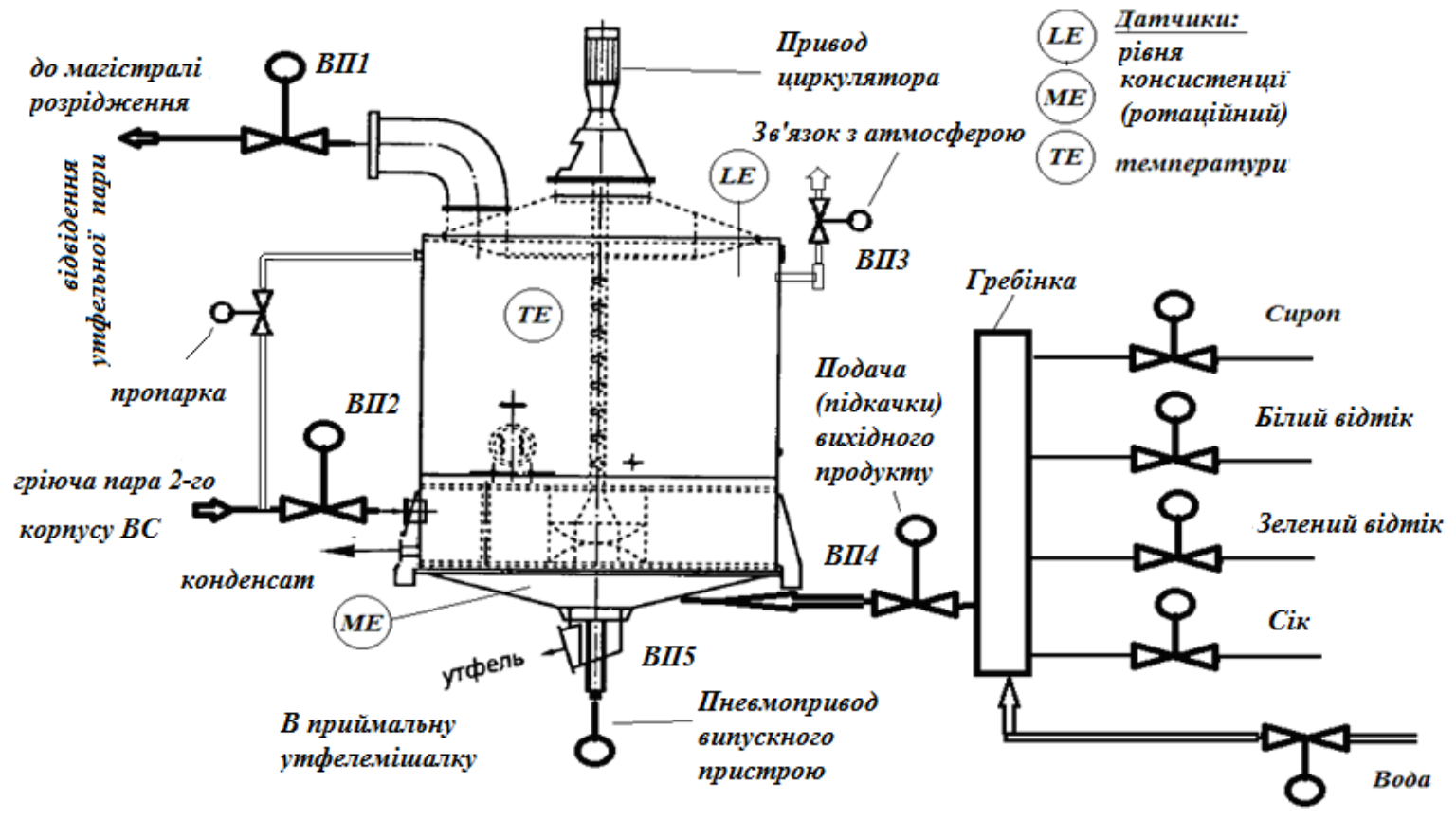

Рис. 1 - Апаратурно-технологічна схема ВА періодичної дії

Fig. 1 - Equipment and technological scheme of batch pan (VA)

Таким чином, основним завданням дослідження було розробити алгоритм і програму оперативного обліку утфелю 3 використанням мови програмування для мікропроцесорного контролера МІК52 та дослідити їі роботу в лабораторних умовах, і за отриманням успішного результату, на базі зазначеного контролера, інтегрувати їі до складу APM оператора з використанням SCADA-системи «ІНДЕЛ», що дозволить у подальшому включити цей АРМ у склад АСКТП продуктового відділення і заводу в цілому, тобто підключити до існуючої заводської інформаційної мережі.

\section{Методи та матеріали досліджень}

Під час виконання передпроєктних досліджень використовувались методи порівняльного аналізу варіантів структури підсистеми оперативного обліку утфелю із застосуванням різних технічних та програмних засобів, 3 урахуванням факторів, що викладені вище, стосовно попередньо створених на заводі систем керування. Остаточні технічні рішення приймалися на основі критерію «ціна-якість» із перевіркою працездатності системи методами імітаційного моделювання. У процесі імітаційного моделювання був використаний лабораторний стенд, котрий було оснащено промисловим контролером: МІК52, аналоговими задатчиками РЗД-22 (зі струмовим виходом 4,...,20 мА), дискретними задатчиками $(0 ; 24$ В), блоком перетворення інтерфейсів БПІ-52, комп'ютером із інстальованим програмним забезпеченням, зокрема: драйвером для БПI-52, SCADA-системою «IНДЕЛ» 3 драйвером MODBUS RTU, котрий надає можливості створити інформаційний шлюз між комп'ютером та контролерами за допомогою двохпровідного інтерфейсу RS-485.

В основу запропонованого метода автоматичного оперативного обліку утфелю положено традиційну методику обліку виробництва [4].

Для оцінювання оптимальної періодичності опитування даних, котра виключала би втрату інформації, було застосовано відому інженерну методику, котра базується на наслідку із теореми Котельникова.

\section{Результати дослідження. Основні остаточні технічні рішення}

Для продуктового відділення задача автоматичного оперативного обліку утфелю складається із двох підзадач: «Розрахунок кількості звареного утфелю за зміну» і «Визначення кількості утфелю, що знаходиться на верстаті». Розглянемо рішення цих задач, що реалізуються у складі АСКТП продуктового відділення. 
Підзадача «Розрахунок кількості звареного утфелю за зміну» вирішується за наступним алгоритмом. На основі сигналу від датчика рівня у ВА визначається кількість утфелю в ньому. Залежність маси утфелю у ВА від рівня в ньому $P=P(h)$ може бути суттєво нелінійною, тому доцільно використовувати у програмній реалізації алгоритмічний блок (АБ) 3 бібліотеки програмування контролера MIK52, що відбиває функцію кусково-лінійної апроксимації LINEAR (52).

Маса утфелю в апараті визначається як

$$
P=V(\mathrm{~h}) \cdot \rho,
$$

де $P$-маса утфелю в ВА, т;

$V(\mathrm{~h})$ - об'єм ВА, що заповнений продуктом (утфелем), як функція рівня в ньому, м³

$\rho$ - щильність утфелю, кг/ $\mathrm{M}^{3}$.

Для вимірювання рівня в ВА, котрий працює під розрідженням, використовують так званий п’єзометричний (з продувкою) метод вимірювання з використанням дифманометру.

Для підготовки вихідних даних для налагодження АБ LINEAR (52) використовують спеціальні таблиці, в яких означена функція $V(\mathrm{~h})$ наведена 3 високою точністю, та архівні дані попередніх варок ВА, що досліджується, про щільність продукту в апараті на різних стадіях уварювання утфелю та вмісту сухих речовин (CР) у ньому. Названі дані зберігаються у службі головного технолога.

Розглянемо програму, складену мовою програмування «а» для контролера МІК52, що реалізує автоматичний оперативний облік утфелю, котрий зварений в ВА за зміну. Програма складалася з урахуванням середньостатистичної тривалості циклу варки утфелю 1-го продукту, котра складає 3,5,..,3,8 години. Відповідно за зміну, що складає 12 -ть годин, кількість варок не може перевищити чотирьох подібних циклів.

На рис. 2 наведено програму складену для ВА№3. Програма реалізує наступний алгоритм. Сигнал пропорційний рівню у BA (у \%) формується в промисловому варіанті реалізації програми на виході 05 (\% рівня у ВА) АБ АIN(05) 10 та подається на вхід АБ LINEAR (52) 17, а в варіанті програми для моделювання відповідно з АБ, що імітує зміну рівня [1]. Нумерація АБ виконується автоматично програмою і остаточно фіксується напередодні розробки SCADA-системи для APM.

Сигнал пропорційний масі утфелю, що знаходиться у ВА, формується у АБ LINEAR (52) 17 та подається 3 виходу OUT (02) на вхід INT (02) АБ MEM(43) 1 (пам'ять). Числове значення маси утфелю у ВА фіксується на виході АБ 1 під час приходу на його вхід eWR (01) прямокутного імпульсу з АБ OSC(40) 15 (одновібратор) (зміна значення 3 «0» на «1») та це значення зберігається на виході АБ 1 до приходу наступного імпульсу на вхід 01. Фіксація наприкінці циклу уварювання значення кількості утфелю у ВА реалізується за сигналом відключення апарата (тумблер Т3 «Основне розрідження» на пульті керування ВА) від магістралі вакууму - тобто за появою сигналу «1» на виході АБ DIN(06) 2. Останній сигнал подається на вхід одновібратора АБ 23 де формується імпульс тривалістю 5 сек., що забезпечує надійну передачу імпульсу до входу eUP (01) АБ COUNT(39) 13 (лічильник). На виході OUT (03) останнього АБ 13 формується порядковий номер імпульсу, що надійшов на лічильник, і передається на вхід АБ CASE(84) 16 (перемикач за номером), що забезпечує формування сигналу «1» на відповідному виході dOT1 АБ 16. За появою наступного імпульсу відповідного закінченню наступної варки (від Т3) аналогічні процедури призведуть до формування сигналу «1» відповідно на виході dOT2 АБ 16, що дозволить формувати процедури для обчислення кількості утфелю, що зварений за другою варкою ВА.

Сигнал «1» на виході dOT1 АБ 16 запускає обновібратор АБ15, котрий формує імпульс тривалістю 10 хвилин, що забезпечує з одного боку фіксацію сигналу числового значення маси утфелю у ВА (наприкінці відповідної варки) на виході АБ 1, як показано вище, так і з другого боку, керування, через АБ ХOR(23) 20 (АБО, що виключає), інтегратором АБ INTEG (17) 22. На вхід INP(02) інтегратора АБ 22 подається сигнал з виходу АБ 1, а інтегрування триває на протязі 10 хвилин, що визначається сигналом з АБ 20, який поступає на відповідні входи інтегратора (03) та (04), як дозвіл на інтегрування. Тривалість інтегрування - 10 хвилин обрана для зручності масштабування сигналу на виході OUT (03) АБ 22, котрий пропорційний кількості утфелю, що зварено за першою варкою, з масштабним коефіцієнтом Км = 6,00. Сигнал 3 виходу OUT (03) АБ 22 подається вхід INP1 (01) суматора АБ SUMM(13) 19, на відповідні входи котрого подаються сигнали пропорційні кількості утфелю, що зварений за іншими наступними варками. Таким чином на виході AБ SUMM(13) 19 формується, завдяки масштабування зі зворотними коефіцієнтами (gain $1, \ldots, 4=0,1666$ ), чисельне значення кількості утфелю звареного за поточну зміну.

Скидання даних обліку виконується з інтервалом тривалості зміни (12-ть годин) шляхом подання сигналу «1» на відповідні входи dRST усіх АБ де вони зберігаються. Означену функцію реалізують АБ ТIMER(38) 6, OR(21) 5 та dSET(83) 9. Початковий момент циклу скидання даних автоматичного обліку утфелю за узгодженням зі службою головного технолога визначається на початку наступної зміни і задається з допоміжної екранної форми АРМ оператора-варщика шляхом зміни параметра (01) налаштування АБ dSET(83) 9 наступним чином: dSET=0-1-0.

Проведене імітаційне моделювання з використанням лабораторного стенду, згаданого вище, дозволило оцінити складену програму як працездатну, і визначити відносну похибку наведеного методу розрахунку, що склала за результатами випробувань $0,25 \%$.

На рис. 3 наведений фрагмент програми автоматичного обліку звареного утфелю, що працює у режимі налагодження після третій варки утфелю.

Оцінювання відносної похибки методу виконувалось за порівнянням суми чисельних значень кількості звареного утфелю $P_{i}$ за три варки, що зберігається в АБ $1,7,11$ (пам'ять) та аналогічного значення $P_{\text {sum }}$ на виході АБ 30 (суматор). 

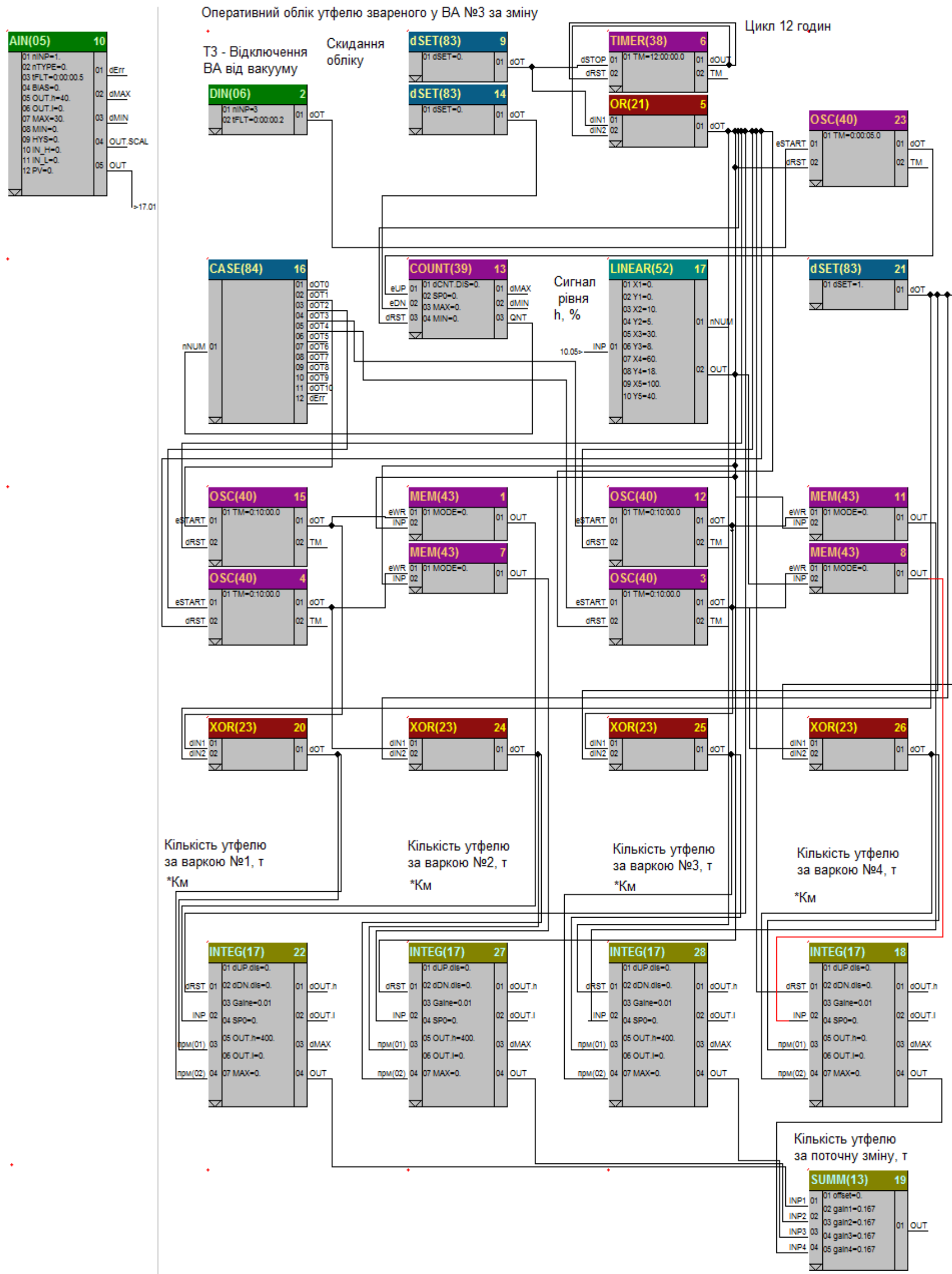

Рис. 2 - Програма обліку звареного утфелю за зміну

Fig. 2 - The program of accounting for massecuite per shift 


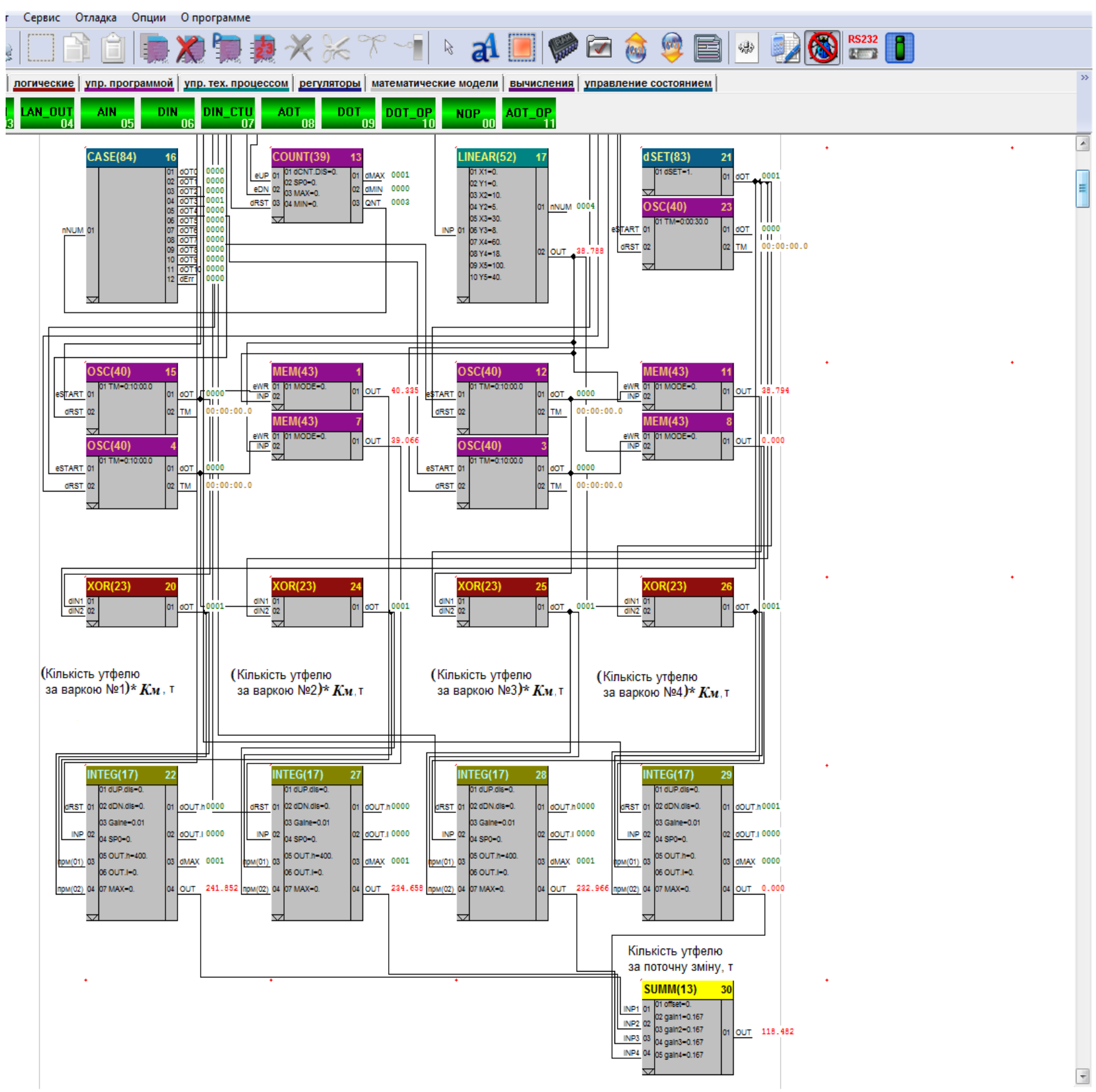

Рис. 3 - Фрагмент програми обліку звареного утфелю за зміну

Fig. 3 - The program's fragment of accounting for massecuite per shift

Тобто відносна похибка методу складає:

$$
\varepsilon=\frac{P_{\text {sum }}-\sum_{i=1}^{3} P_{i}}{\sum_{i=1}^{3} P_{i}} \cdot 100 \%=\frac{118,48-(40,33+39,06+38,79)}{118,18} \cdot 100 \%=0,25 \% .
$$

Ця похибка виникає під час інтегрування з фіксацією моментів дозволу та заборони інтегрування у АБ INTEG (17) та округлення даних.

Загальна відносна похибка складається з вищенаведеної, похибки апроксимації нелінійної залежності $P=V(\mathrm{~h}) \cdot \rho($ не перевищує 0,2 \% за даними підприємства) та похибки вимірювання рівня утфелю у ВА з використанням дифманометра 3 класом точності 0,5. Таким чином, загальну відносну похибку автоматичного оперативного обліку звареного утфелю у ВА можна оцінити як таку, що складає менш одного відсотка, що для подібних задач є досить прийнятною, враховуючі що ці 
розрахунки не відносяться до класу комерційних та те, що аналогічні похибки за ручним вимірюванням та розрахунками перевищують 4 - 5\% [2].

Інтегрування розробленої програми в програму моделювання САК ВА, дозволяє реалізувати одночасно обидві задачі в складі АРМ оператора-варщика. В процесі складання інтегрованої програми виконується остаточна нумерація АБ та визначення номерів відповідних регістрів пам'яті, де зберігаються поточні числові значення змінних для зручності налагодження екранних форм у SCADA-системі.

На рис. 4 наведена інтегрована програма керування ВА (з програмою моделі об'єкту керування - ОК) та оперативного обліку кількості звареного утфелю за зміну для ВА №3.
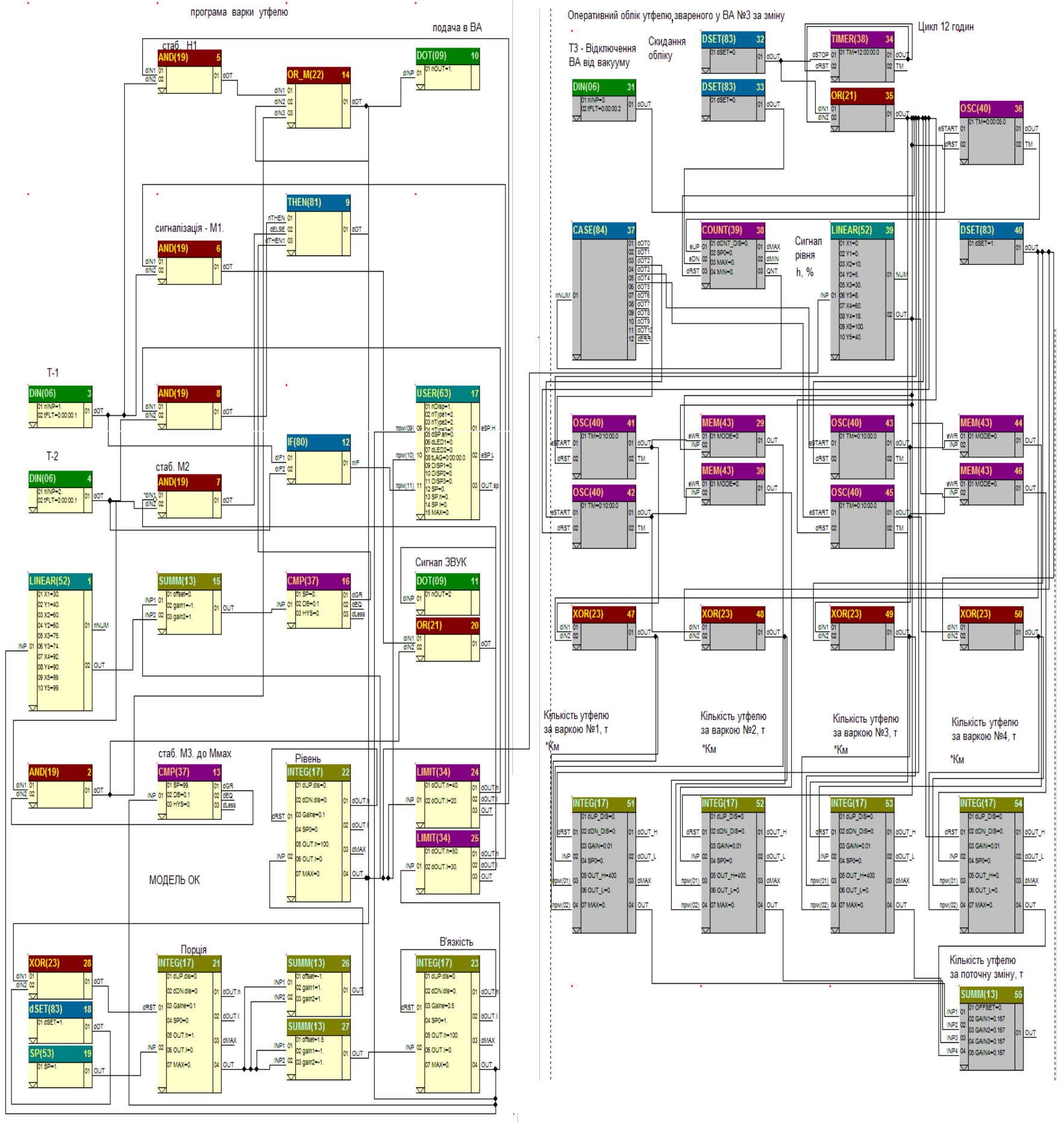

Рис. 4 - Програма керування та обліку звареного утфелю за зміну у ВА №3

Fig. 4 - Controlling and accounting program for massecuite per shift in VA № 3 
Отримані дані за кількістю звареного утфелю наводяться на основній екранній формі ВА№3 першого продукту оператора-варщика (рис. 5), де також наведена доповнена опцією «Скидання даних оперативного обліку звареного утфелю» допоміжна форма для налаштування програм.

Аналогічно наведеним рішенням, реалізуються задачі обліку звареного утфелю у інших ВА першого продукту.
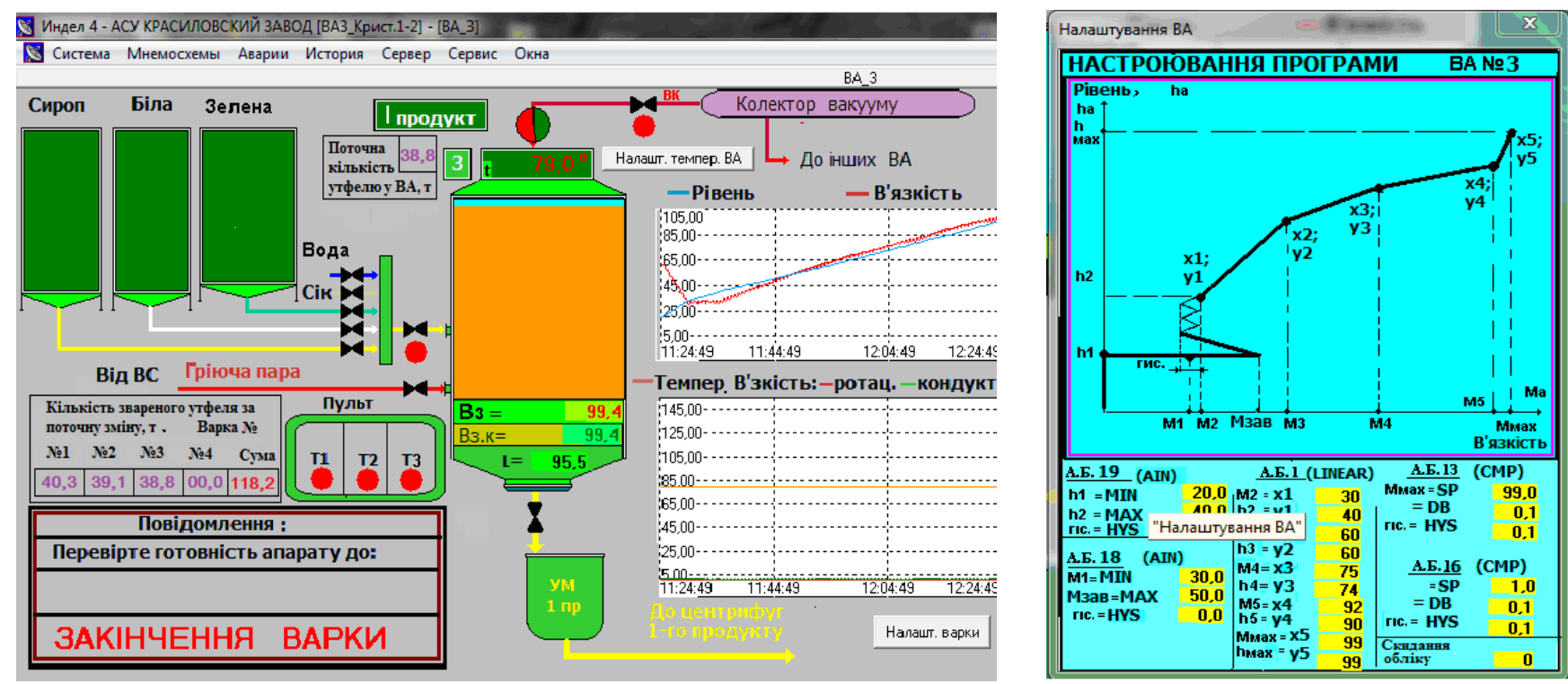

Рис. 5 - Основна екранна форма АРМ оператора-варщика на стадії закінчення варки №3 та доповнена форма для налагодження програм

Fig. 5 - The main screen form of operator-cooker's AWP in the end of cooking stage №3 and the supplemented form for debugging programs

Сумарна кількість утфелю, що зварена у всіх ВА першого продукту відділення, котре розглядається, обчислюється складанням отриманих чисельних значень для кожного BA засобами SCADA-системи та наводяться на загальній екранній формі оператора відділення.

Розглянемо рішення другої підзадачі, котру доцільно вирішувати у складі АСКТП продуктового відділення «Визначення кількості утфелю, що знаходиться на верстаті».

Традиційно верстат утфелю розраховують для кожного продукту. Розглянемо рішення цієї підзадачі на прикладі автоматичних розрахунків для першого продукту.

Кількість (маса) утфелю, що знаходиться на верстаті першого продукту, визначається шляхом підсумовування поточної кількості утфелю, що знаходиться у ВА першого продукту, утфелемішалках і кількості утфелю, отриманого за перерахуванням маси напівпродукту (на масу утфелю) у сиропних збірниках та збірниках білого відтоку (патоки) [4]. За технологічною схемою даного відділення, у збірники сиропу поступає також клеровка цукру останньої кристалізації. За узгодженням з головним технологом заводу в даній методиці не враховувався верстат сокових (досиропних) збірників і утфель, що знаходиться в утфелерозподільнику перед центрифугами.

Кількість (маса) утфелю, що знаходиться на верстаті 1-ої кристалізації в будь-який момент часу в загальному випадку визначається відповідно до традиційної методики за формулою:

$$
P_{\text {sum }}^{1}(t)=\sum_{i=1}^{n} K_{i} \cdot \int_{0}^{H} S_{i}\left[h_{i}(t)\right] \cdot d h_{i}(t),
$$

де $P_{\text {sum }}^{1}(t)$ - поточне миттєве значення маси утфелю 1-го продукту, т;

$K i$ - коефіцієнт перерахування обсягу даного напівпродукту на масу утфелю, т/м³

$S_{i}\left[h_{i}(t)\right]$ - поточне значення площі перерізу і-го апарата, при даному миттєвому значенні рівня напівпродукту в ньому, м²; $h(t)$ - поточне миттєве значення рівня напівпродукту в і-ому апараті, м;

$[0 ; H]$ - діапазон вимірюваного значення рівня в апараті, м;

$i$ - номер апарата.

Перерахування маси напівпродукту на масу утфелю виконують з урахуванням вмісту у них сухих речовин та щільності. Початкові значення коефіцієнтів перерахування $K i$ задаються, виходячи з даних технічного відділу заводу і уточнюються в процесі роботи.

Оцінювання поточних значень кількості напівпродукту в кожному апараті з урахуванням залежності площі перерізу від рівня в різних за конструкцією апаратах можна виконати декількома методами. 
В першому - функції $\mathrm{Si}[\mathrm{hi}(\mathrm{t})]$ апроксимуються набором математичних залежностей, виходячи $з$ конструктивних особливостей апарата. В другому - використовуються таблиці посантиметрового перерахування рівня на масу напівпродукту в кожному апараті з урахуванням, в обох випадках, щильності та середнього вмісту СР у них. Названі таблиці знаходяться у відділі головного технолога і використовуються при проведенні аналогічних розрахунків вручну. Таким чином, залежність (1) може бути представлена у вигляді:

$$
P_{\text {sum }}^{1}(t)=\sum_{i=1}^{n} P_{i}\left[h_{i}(t)\right]
$$

Функції $P_{i}\left[h_{i}(t)\right]$, у випадках істотної нелінійності, можуть бути апроксимовані кусково-лінійними залежностями, як це виконано за програмної реалізації першої підзадачі для ВА. Аналогічний метод може бути використаний для оцінювання кількості утфелю, котрий знаходиться в утфелемішалках. Як показано у [2], другий метод виявився більш зручним у практичній реалізації і давав задовільну точність розрахунків. Слід зазначити, що автоматизований розрахунок за (2) $є$ у всіх випадках більш точним, ніж ручний. Для збірників напівпродуктів (сиропу з клеровкою та білої патоки) характерна залежність кількості продукту від рівня в них близька до лінійної. Тому для них залежність (2) реалізується за спрощеною лінійною формулою. Відповідні коефіцієнти оцінюються також за даними служби головного технолога.

Таким чином, алгоритми рішення підзадачі «Визначення кількості утфелю, що знаходиться на верстаті 1-го продукту» реалізуються програмно за наведеною методикою, з використанням поточних даних, отриманих для кожного ВА 1-го продукту у підзадачі «Розрахунок кількості звареного утфелю за зміну».

Остаточні результати автоматичних розрахунків за обома підзадачами, а саме: сумарна кількість утфелю, що зварена у всіх ВА першого продукту відділення, та кількість утфелю що знаходиться на верстаті 1-го продукту, обчислюється складанням отриманих чисельних значень засобами SCADA-системи та наводяться на загальній екранній формі оператора продуктового відділення. Крім того, отримані результати архівуються засобами SCADA-системи, що дозволяє персоналу проводити необхідний аналіз результатів роботи кожної зміни та своєчасно вносити необхідні корективи в режими роботи продуктового відділення.

Аналогічно, за наведеною методикою можуть автоматично розраховуватись показники кількості утфелю на верстаті 2го та 3-го продуктів (за реалізацією трипродуктової технологічної схеми відділення).

\section{Обговорення результатів}

Отримані результати проведеного дослідження дозволяють зробити висновки про працездатність розробленої підсистеми автоматичного оперативного обліку утфелю, що зварений у ВА періодичної дії. Інтегрування програми оперативного обліку до програми керування, дозволило розширити перелік функцій САК ВА, підвищити інтелектуальність пропонованої системи та склали умови для модернізації АСКТП продуктового відділення цукрового заводу на основі отриманих позитивних результатів. Імітаційне моделювання на спеціалізованому лабораторному стенді в середовище промислового програмованого контролера МІК52 дозволило оцінити похибку розрахунків, як таку, що складає менш одного відсотка, що для подібних промислових систем є прийнятною. Отримані результати архівуються засобами SCADA-системи, що дозволяє персоналу проводити необхідний аналіз результатів роботи кожної зміни та своєчасно вносити необхідні корективи в режими роботи продуктового відділення, проводити оперативні заходи для поліпшення техніко-економічних показників роботи відділення та заводу в цілому.

Подальші дослідження будуть спрямовані на визначення остаточної структури комплексу інтелектуальних технічних засобів для реалізації АСКТП продуктового відділення, що будується на основі контролерно комп’ютерної мережі з наступним підключенням до інформаційної мережі АСКТП заводу. В модернізованій АСКТП відділення пропонується використати промислові комп'ютери, що обумовлено складними умовами повітряного середовища операторського пункту (ОП) продуктового відділення, а саме високою температурою та підвищеною вологістю. Для зменшення цих шкідливих факторів як для оператора, так і для технічних засобів в ОП необхідно використаня примусової вентиляції.

\section{Висновки}

Проведені передпроєктні дослідження з використанням методів імітаційного моделювання на спеціалізованому стенді, котрий було обладнано промисловим устаткуванням, дозволили розробити комплекс технічних рішень, в тому числі алгоритмів і програм, що забезпечує розширення функцій САК ВА. Функції автоматизованого керування процесами у ВА доповнені функціями автоматичного обліку утфелю, котрий зварено у ВА першого продукту за зміну та того, що знаходиться на верстаті. Автоматизація задач оперативного обліку суттєво полегшує роботу керівництва служби головного технолога і сприяє підвищенню техніко-економічних показників роботи відділення та заводу в цілому, за рахунок своєчасного прийняття необхідних рішень 3 коректування режимів на основі об'єктивної інформації, виключення впливу людського фактору та додаткових похибок в розрахунках показників роботи відділення.

Технічні і програмні засоби Українського виробництва забезпечують достатню точність підтримання регламентів ведення процесу та розрахунків характерних показників обліку виробництва, досить комфортні умови праці, як оперативному персоналу, так і технічним керівникам підприємства для аналізу технологічних процесів.

На основі отриманих позитивних результатів проведеного дослідження розроблена промислова версія АРМ оператора-варщика, з розширенням інтелектуальних функцій системи, та запропонована керівництву підприємства до впровадження. 
Виконаний комплекс досліджень дозволяє зробити висновок про доцільність продовження робіт із модернізації систем керування підприємства, використовуючи принцип проєктування АСКТП - «знизу вгору», а також наведені методи й підходи до прийняття основних технічних рішень 3 використанням вітчизняних технічних і програмних засобів.

\section{Список використаних джерел}

[1] Скаковський Ю. М. Модернізація системи автоматизованого керування вакуум-апаратом періодичної дії цукрового виробництва на базі технічних і програмних засобів українського виробництва/ Ю. М. Скаковський, А. В. Бабков, О.Ю. Мандро// Автоматизація технологічних и бизнес-процесів. - Одеса: 2019 - том11 №3, С. 4-14.

[2] Вітвицький В.Д. Рішення задач оперативного обліку в АСУТП ділянок цукрового виробництва/ В.Д.Вітвицький, Ю.М. Скаковський//Наукові праці ОНАХТ/ МОН України. - Одеса: 2004 - Вип. 27, С. 213-221.

[3] Скаковский Ю.М. Использование микропроцессорных контроллеров и программ украинского производства для модернизации системы управления диффузионного отделения сахарного завода/ Ю.М. Скаковский, А.В. Бабков// Автоматизація технологічних і бізнес-процесів / Щоквартальний Міжнародний науково-виробничий журнал.- том 7, № 3, - Одеса: ОНАХТ, 2015, С. 49-51.

[4] Приймак В.М. Технология и технохимконтроль сахарного производства/В.М. Приймак. -М.: Легкая и пищевая пром-сть, 1981. -240 с.

\section{References}

[1] Skakovskij Yu. M. Modernizaciya sistemi avtomatizovanogo keruvannya vakuum-aparatom periodichnoyi diyi cukrovogo virobnictva na bazi tehnichnih i programnih zasobiv ukrayinskogo virobnictva/ Yu. M. Skakovskij, A. V. Babkov, O.Yu. Mandro// Avtomatizaciya tehnologichnih i biznes-procesiv. - Odesa: 2019 - tom11 №3, s. 4-14.

[2] Vitvickij V.D. Rishennya zadach operativnogo obliku v ASUTP dilyanok cukrovogo virobnictva/ V.D.Vitvickij, Yu.M. Skakovskij//Naukovi praci ONAHT/ MON Ukrayini. - Odesa: 2004 - Vip. 27, S. 213-221.

[3] Skakovskij Yu.M. Ispolzovanie mikroprocessornyh kontrollerov i programm ukrainskogo proizvodstva dlya modernizacii sistemy upravleniya diffuzionnogo otdeleniya saharnogo zavoda/ Yu.M. Skakovskij, A.V. Babkov// Avtomatizaciya tehnologichnih i biznes-procesiv / Shokvartalnij Mizhnarodnij naukovo-virobnichij zhurnal.- tom 7, № 3, - Odesa: ONAHT, 2015, S. 49-51.

[4] Prijmak V.M. Tehnologiya i tehnohimkontrol saharnogo proizvodstva/V.M. Prijmak. -M.: Legkaya i pishevaya prom-st, 1981. $-240 \mathrm{~s}$.

\section{УДК 658.5.011.16}

\section{THE TECHNICAL OBJECTS' EFFICIENCY CONTROL BY THEIR RENEWAL}

\section{Voinova S.A.}

Odessa National Academy of Food Technologies, Odessa, Ukraine

ORCID: http://orcid.org/0000-0003-0203-0599

E- mail: voinova_s@yahoo.com

Copyright (C) 2020 by author and the journal "Automation of technological and business-processes". This work is licensed under the Creative Commons Attribution International License (CC BY). http://creativecommons.org/licanses/by/4.0

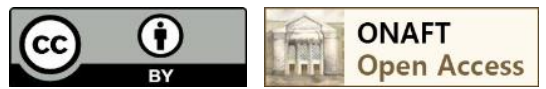

DOI: https://doi.org/10.15673/atbp.v12i3.1923

Анотація. Ступінь функиіонального вдосконалення технічного об'єкта характеризується рівнем його технологічної ефективності. У процесі експлуатації технічного об'єкта відбувається його знос, який знижує рівень його ефективності. Високопродуктивним методом управління рівнем технологічної ефективності технічного об'єкта є його оновлення. Здійснення оновлення є актуальною задачею. Оновлення як дія може бути частковим, повним і комплексним. Відповідно до складності багатогранного завдання оновлення виробництва, його предметний простір слід розділити на п'ять частин. Розглянуто складові основних елементів кожної частини, які підлягають оновленню. Показано місие та роль кожної частини у впливі їх на формування технологічної ефективності технічного об'єкта. Показано також вплив ступеня зносу технічного об'єкта. Особливої уваги заслуговує проблема 